\title{
Faktor-Faktor Keberhasilan Implementasi Kebijakan Pengelolaan Limbah Kelapa Sawit Di Kabupaten Rokan Hulu
}

\author{
${ }^{1}$ Dia Meirina Suri, ${ }^{2}$ Muhammad Faisal Amrillah \\ ${ }^{12}$ Fakultas Ilmu Sosial dan Ilmu Politik, Universitas Islam Riau, Indonesia \\ e-mail: diameirinasuri@soc.uir.ac.id
}

\begin{abstract}
Abstrak
Tujuan dari penelitian ini adalah untuk melihat factor-faktor keberhasilan implementasi kebijakan dalam pemanfaatan limbah kelapa sawit. Limbah kelapa sawit yang menyebabkan pencemaran dimanfaatkan menjadi energy listrik dan mampu memberikan kontribusi listrik bagi masyarakat sekitar yang belum mendapatkan aliran listrik dari PLN. Pengumpulan data dilakukan melalui wawancara dan observasi. Data yang terkumpul dianalisa dengan menggunakan pendekatan kualitatif dengan teknik triangulasi data dan disajikan dalam bentuk deskriptif. Hasil penelitian menemukan bahwa faktor-faktor keberhasilan dalam implementasi kebijakan pemanfaatan limbah kelapa sawit adalah adanya kejelasan program dan tingkat kesepakatan diantara pelaksana kebijakan yaitu adanya kejelasan pasokan limbah yang akan diolah menjadi energy listrik, adanya lahan yang akan dimanfaatkan sebagai tempat pengolahan dan komitmen dari pelaksana, kemudian adanya perubahan dari penerima manfaat yaitu masyarakat yang dulunya tidak mendapat aliran listrik mulai merasakan adanya listrik selama 24 jam sehingga produktivitas mereka bisa meningkat, dan tipe dari masyarakat penerima manfaat.
\end{abstract}

Keywords: implementasi, energy listrik, limbah kelapa sawit

\begin{abstract}
The purpose of this research is to look at the factors of policy implementation in oil palm waste management. Oil palm waste that causes pollution is used to become electrical energy and is able to contribute electricity to surrounding communities who have not yet received electricity from PLN. Data collection was carried out through interviews and observations. The data were analyzed using a qualitative approach with data triangulation techniques and presented in a descriptive form. The results found that the factors in the implementation of palm oil waste management were the existence of a program of clarity and agreement among policy implementers, namely the clarity of the supply of waste to be processed into electricity, the existence of land to be used as a place for processing and commitment from the executor, Then there was a change from the beneficiaries, namely that people who previously did not have electricity began to feel electricity for 24 hours so that their productivity could increase, and from the beneficiaries.
\end{abstract}

Kata Kunci : implementation, electrical energy, palm oil waste 


\section{PENDAHULUAN}

Kerusakan lingkungan menjadi isu yang sering dibicarakan, salah satu kerusakan lingkungan diakibatkan oleh banyaknya limbah dari hasil perkebunan kelapa sawit. Banyaknya perkebunan kelapa sawit berbanding lurus dengan limbah yang dihasilkan dari proses pengelolaan kelapa sawit tersebut. Kabupaten Rokan Hulu merupakan salah satu kabupaten dengan lahan perkebunan kelapa sawit yang banyak. Banyaknya lahan perkebunan tentu saja membutuhkan perusahaan pengelolaan kelapa sawit. Perusahaan pengelolaan kelapa sawit inilah yang kemudian menghasilkan limbah hasil olahan kelapa sawit. Keberadaan perusahaan pengolahan kelapa sawit ini memberikan kemudahan bagi masyarakat untuk menjual hasil perkebunannya. Konsekuansi dari adanya perusahaan pengolahan kelapa sawit ini adalah menumpuknya limbah yang bisa membahayakan masyarakat disekitar perusahaan tersebut.

Berdasarkan Peraturan Menteri ESDM Nomor 10 Tahun 2012 Tentang Pelaksanaan Kegiatan Fisik Pemanfaatan Energi Baru dan Energi Terbarukan, Pemerintah Kabupaten Rokan Hulu membangun sebuah pembangkit listrik dengan memanfaatkan limbah yang dihasilkan dari pengelolaan kelapa sawit melalui program desa mandiri energy. Program ini bertujuan untuk menyediakan energy listrik bagi desa yang belum mendapatkan aliran listrik dari PLN yang bersumber dari energy baru dan terbarukan. Program pembangunan PLTBg ini merupakan salah satu bentuk pemanfaatan potensi limbah pertanian yang tersebar di seluruh Provinsi di Indonesia yang dapat menjadi solusi bagi daerah-daerah yang sampai saat ini masih belum mendapat akses listrik PLN dan tidak memungkinkan untuk ditarik jaringan listrik PLN. Kabupaten Rokan Hulu merupakan kabupaten yang berhasil dalam melaksanakan program tersebut dan mampu mengaliri desa-desa yang berada disekitar pembangkit listrik tersebut.

Keberhasilan sebuah kebijakan dapat dilihat dari bagaimana pelaksana megimplementasikan kebijakan tersebut. Menurut Nogi (2003 : 13) implementasi kebijakan merupakan rangkaian kegiatan setelah suatu kebijakan dirumuskan, tanpa suatu implementasi maka suatu kebijakan yang telah dirumuskan akan sia-sia. Sedangkan menurut Grindle (1980 : 18) implementasi kebijakan sesungguhnya bukan sekedar berhubungan dengan mekanisme penjabaran atau operasional dari keputusan politik ke dalam prosedur-prosedur rutin lewat saluran birokrasi melainkan lebih dari itu yaitu menyangkut masalah konflik, keputusan dan siapa yang akan memperoleh apa dan suatu kebijakan. Implementasi kebijakan pada prinsipnya adalah cara agar sebuah kebijakan dapat mencapai tujuannya. Tidak lebih dan tidak kurang. Untuk mengimplementasikan kebijakan publik, maka ada dua langkah yang ada yaitu langsung mengimplementasikan dalam bentuk, program-program atau melalui formulasi kebijakan derivate atau turunan dari kebijakan publik tersebut. (Nugroho, $2003: 158$ ).

Secara jujur dapat dikatakan bahwa, setiap kebijakan sebaik apapun sebenarnya mengandung resiko untuk gagal (policy failure) sebagaimana diungkapkan oleh Hogwood dan Gunn (dalam Sumaryadi, 2005 : 84) yakni non implementation atau tidak terimplementasikan dan kategori unsuccessful implementation atau implementasi yang tidak berhasil. Non implementation berarti suatu kebijakan tidak dilaksanakan sesuai rencana, mungkin karena pihak yang terlibat pelaksanaannya tidak mau bekerja sama atau telah bekerja sama secara tidak efisien, bekerja setengah hati, atau karena tidak sepenuhnya menguasai permasalahan, atau kemungkinan permasalahn yang diseleseikan di luar jangkauan kekuasaannya sehingga betapapun gigihnya usaha mereka, hambatan yang ada tidak sanggup di tanggulangi.

Akibatnya implementasi yang efektif sukar dipenuhi. Keberhasilan suatu program dapat dilihat jika program itu berjalan sesuai dengan pola-pola yang telah ditetapkan. Linders and Peters memberikan alternatif dalam menafsirkan keberhasilan implementasi dengan mengevaluasi kinerja kebijakan dan berusaha menentukan ada atau tidaknya perubahan yang nyata dalam populasi target atau kondisi sebagai akibat suatu intervensi kebijakan pemerintah. Faktor-faktor keberhasilan implementasi menurut Ripley dan Franklin dalam Sujianto (2008 : 46) adalah : 
1. Kejelasan tujuan-tujuan program dan tingkat konsensus diantara pelaksana atas tujuan-tujuan tersebut.

2. Tingkat perubahan dari kebiasaan-kebiasaan lama yang dikehendaki program.

3. Tipe-tipe orang yang memperoleh manfaat dan klien terbatas, yaitu orang dan kelompok yang menjadi target implementasi.

Apabila kelompok-kelompok penting dari mereka (kelompok sasaran) mempunya tingkat konsensus yang tinggi untuk mentang implementasi, maka tidak mungkin implementasi dapat berhasil. Namun bila kelompok-kelompok penting tersebut berada pada suatu pandangan dalam implementasi maka implementasi akan dibuat lebih mudah (Sujianto : 47).

\section{METODE}

Penelitian ini menggunakan pendekatan deskriptif kualitatif dengan menggunakan informan penelitian sebagai sumber informasi untuk memperoleh data yang dibutuhkan dalam melihat factor-faktor keberhasilan dalam implmentasi kebijakan pengelolaan limbah kelapa sawit di Kabupaten Rokan Hulu. Adapun tehnik yang digunakan dalam memperoleh informan penelitian ini adalah tehnik snowball sampling yaitu sebuah tehnik penentuan sumber informasi seperti bola salju yang mengelinding untuk menemukan sumber informasi yang paling tepat dalam memberikan tanggapan tentang implementasi kebijakan lingkungan (studi pemanfaatan limbah kelapa sawit menjadi energy listrik). Setelah data terkumpul dari setiap infoman penelitian, kemudian akan digunakan metode triangulasi dengan cek and cross cek terhadap hasil tanggapan yang diberikan informan penelitian.

\section{HASIL DAN PEMBAHASAN}

Faktor-faktor keberhasilan implementasi kebijakan pengelolaan limbah kelapa sawit di Kabupaten Rokan Hulu terdiri dari :

1. Kejelasan tujuan-tujuan program dan tingkat konsensus diantara pelaksana atas tujuan-tujuan tersebut. Sebuah implementasi dapat dilaksanakan apabila memiliki tujuan yang jelas dan dapat diukur. Adapun tujuan dari progam pembangunan pembangkit listrik menggunakan tenaga biogas di Kabupaten Rokan Hulu adalah untuk mengatasi banyaknya limbah yang dihasilkan dari perusahaan pengelolaan kelapa sawit. Limbah ini dapat mencemari lingkungan dan bisa menyebabkan berbagai penyakit bagi masyarakat sekitarnya. Selain tujuan tersebut, program ini ini juga bertujuan untuk menciptakan desa mandiri energy, yaitu desa yang mampu menghasilkan aliran listrik dari pemanfaataan sumberdaya baru dan terbarukan yang mereka ciptakan sendiri. Tujuan dari program ini didukung oleh pemerintah Kabupaten Rokan Hulu dengan dikeluarkannya Surat Keputusan Bupati Rokan Hulu Nomor : Kpts.671/Distamben-Be/262/2015 tentang Penetapan Desa Dalam Wilayah Kecamatan Tambusai Utara Sebagai Desa Mandiri Energi sehingga program ini memiliki dukungan penuh dari pemerintah kabupaten.

2. Tingkat perubahan dari kebiasaan-kebiasaan lama yang dikehendaki program.

Perubahan yang paling dirasakan dari pelaksanaan program ini adalah masyarakat yang dapat menikmati listrik yang dulunya tidak tersentuh sama sekali oleh listrik. Selain itu, limbah yang dulunya mencemari lingkungan menjadi bernilai dan dapat dimanfaatkan untuk menjadi energi baru dan terbarukan. 
3. Tipe-tipe orang yang memperoleh manfaat dan klien terbatas, yaitu orang dan kelompok yang menjadi target implementasi

Yang menerima manfaat dari kebijakan ini adalah masyarakat yang berada di sekitar PLTBg tersebut. Ada tiga desa yang merasakan manfaatnya langsung yaitu aliran listrik yang tersambungkan kerumah setiap warga. Masyarakat tidak hanya menerima manfaatnya saja tetapi ikut berperan dan berpartisipasi dalam keberlangsungan program ini yaitu dalam bentuk kontribusi yang diberikan warga desa dalam pembangunan PLTBg dengan menyiapkan lahan dan bersedia mengelola PLTBg Rantau Sakti lewat Badan Usaha Milik Desa (BUMDES) dengan penanggung jawab Kepala Desa Rantau Sakti menunjukkan adanya peran serta dari masyarakat dalam mewujudkan kebijakan lingkungan tersebut.

Selain itu, bentuk dukungan yang diberikan oleh masyarakat adalah adanya sebuah pabrik kelapa sawit (PKS) juga bersedia memberikan pome (limbah kelapa sawit) untuk digunakan sebagai bahan bakar PLTBg selama 20 tahun tanpa kompensasi apapun. Bentuk partisipasi yang diberikan masyarakat Desa Rantau dalam pelaksanaan pembangunan PLTBg adalah menyediakan lahan \pm 2 Ha dengan nilai Rp. 450.000.000, sebagai tempat pengolahan limbah kelapa sawit menjadi energi Biogas. Lahan yang digunakan merupakan lahan-lahan masyarakat yang dibeli oleh Pemerintah Desa Rantau Sakti dalam upaya menyediakan fasilitas tempat pembangunan PLTBg. Proses pembangunan dan pengembangan Desa Mandiri Energi menjadi PLTBg menggunakan dan menghabiskan anggaran dana sekitar \pm 30 milyar rupiah yang berasal dari dana Pemerintah Pusat melalui Kementrian Energi dan Sumber Daya Mineral, Pemerintah Kabupaten Rokan Hulu dan bantuan swadaya masyarakat Desa Rantau Sakti.

\section{KESIMPULAN}

Sebuah kebijakan dapat berhasil dilaksanakan ditunjang oleh berbagai faktor, adapun dalam implementasi kebijakan pemanfaatan limbah kelapa sawit, yang menjadi faktornya adalah adanya kejelasan tujuan-tujuan program dan tingkat konsensus diantara pelaksana atas tujuan-tujuan tersebut, kemudian terdapat tingkat perubahan dari kebiasaan-kebiasaan lama yang dikehendaki program dan yang terakhir adalah tipe-tipe orang yang memperoleh manfaat dan klien terbatas, yaitu bagaiman respon dari masyarakat dalam menjalankan program tersebut.

\section{SARAN}

Adapun saran yang dapat diberikan untuk keberlangsungan program ini adalah adanya pengembangan dalam pemanfataan limbah kelapa sawit sehingga tidak hanya bermanfaat bagi masyarakat sekitar namun bisa menjadi percontohan bagi daerah lainnya yang memiliki perkebunan kelapa sawit yang luas. Kemudian bagi pemerintah untuk dapat memberikan dukungan lebih agar program ini dapat berjalan dengan lancar. 


\section{DAFTAR PUSTAKA}

[1] Abidin.,Zainal 2012., Kebijakan Publik., Penerbit Salemba Humanika., Jakarta

[2] Anderson.E,James 1979.,"Public Policy Making”., Holt, Rinchard \& Winston., New York

[3] Agustino., 2008., Dasar-dasar Kebijakan Publik., Penerbit Alfabeta., Bandung

[4] Dunn.,William 2001., Analisis Kebijakan Publik., diterjemahkan oleh Muhadjir Darwin., Hanindita Graha Widia., Yogyakarta

[5] Dwiyanto., 2009., Kebijakan Publik berbasis Dynamic Policy Analisys., Gava Media., Yogyakarta.

[6] Fischer Frank, et.all., 2015., Handbook of public policy analysis : theory, politics, and methods)., CRS Press Taylor and Francis Group., Boca Raton London New York

[7] Hill dan Hupe., 2002., Implementing Public Policy., SAGE Publications., London

[8]Kusumanegara.,Sollahuddin 2010., Model dan Aktor dalam Proses Kebijakan Publik., Gava Media., Yogyakarta

[9] Nogi.,Hassel 2003., Evaluasi Kebijakan Publik, Penjelasan Analisis dan Transformasi Pikiran Nagel, Balairung \& Co., Yogyakarta

[10] Nugroho., 2008., Public Policy., Alex Media komputindo Gramedia., Jakarta

[11] Parsons.,Wayne 2011., Public Policy : Pengatar Teori dan Praktik Analisis Kebijakan., Kencana Prenada Media Group., Jakarta

[12] Purwanto dan Dyah., 2012., Implementasi Kebijakan Publik : Konsep dan Aplikasinya di Indonesia., Penerbit Gava Media., Yogyakarta

[13] Santoso., 2010., Analisis Kebijakan Publik., Modul Pembelajaran., JPP dan PolGov., Yogyakarta

[14]Subarsono.,AG 2012., Analisis Kebijakan Publik : Konsep, Teori dan Aplikasi., Pustaka Pelajara., Yogyakarta

[15] Suharto., 2005., Analisis Kebijakan Publik., Alfabeta., Bandung

[16] Sujianto., 2008., Implementasi Kebijakan Publik., Penerbit Alaf Riau., Pekanbaru

[17] Tachjan, H. 2008. The Public Policy Implementation. Bandung: AIPI

[18] Wahab.,Solichin Abdul 2012., Analisis Kebijakan Publik : Dari Formulasi ke Penyusunan Modelmodel Implementasi Kebijakan Publik., Bumi Aksara., Jakarta

[19] Winarno.,Budi 2012., Kebijakan Publik : Teori, Proses dan Studi Kasus., Penerbit CAPS., Yogyakarta 